\title{
The Implementation of Civic Education as a Means of Internalizing Nationalism to Primary School Students
}

\section{Inoe Saputro ${ }^{1 *}$, Retno Winarni $^{2}$, Mintasih Indriayu $^{3}$}

1,2,3 Universitas Sebelas Maret, Surakarta, Indonesia

\section{A R T I C LE I N F O}

Article history:

25 December 2020

Received in revised form

01 January 2021

Accepted 25 January

2021

Available online 25

February 2021

Kata Kunci:

Kewarganegaraan,

Nasionalisme.

Keywords:

Civic Education

Nationalism

\begin{abstract}
A B S T R A K
Globalisasi tidak hanya berdampak positif terhadap perkembangan teknologi, tetapi juga dapat berdampak negatif terhadap karakter generasi muda. Di sinilah pendidikan kewarganegaraan sangat diinginkan sebagai ukuran internalisasi nilainilai nasionalisme, sehingga meskipun generasi muda memiliki kompetensi global, mereka tetap mempertahankan nilai-nilai nasionalisme. Penelitian ini bertujuan untuk mendeskripsikan peran guru sebagai pengajar pendidikan kewarganegaraan dalam menginternalisasikan nilai-nilai nasionalisme pada siswa sekolah dasar. Penelitian ini merupakan penelitian deskriptif kualitatif dengan sampel 25 siswa kelas 5 (lima) SD Negeri di Surakarta, Jawa Tengah, Indonesia. Teknik pengumpulan data yang digunakan adalah observasi, angket, dan wawancara. Triangulasi sumber dan teknik digunakan untuk memvalidasi data. Hasil penelitian menunjukkan bahwa intervensi guru sangat vital bagi nilai nasionalisme siswa. Data menunjukkan bahwa $72 \%$ siswa sangat antusias dalam berdiskusi, $82 \%$ sangat toleran terhadap keberagaman, dan $80 \%$ menyukai produk asli Indonesia. Hal ini menunjukkan bahwa intervensi guru juga berkontribusi dalam mengurangi dampak negatif globalisasi, yang secara langsung menentukan sikap nasionalisme siswa.
\end{abstract}

\begin{abstract}
A B S T RA C T
Globalization not only affects positively the technology development, but also can affect negatively the character of young generation. It is here that civic education is very desirable as a measure of internalizing nationalism values, so that although young generations have global competencies, they remain to maintain nationalistic values. This research aims to describe the role of teachers as the instructor of civic education in internalizing nationalism values to primary school students. This was a descriptive qualitative research with 25 5th (fifth) graders in public primary schools in Surakarta, Central Java, Indonesia being the sample. Techniques of collecting data used were observation, questionnaire, and interview. Source and technique triangulations were used to validate the data. The result of research showed that teachers' intervention is very vital to students' nationalistic values. The data shows that $72 \%$ of students have high enthusiasm with discussion, $82 \%$ are very tolerant to diversity, and $80 \%$ love Indonesian original products. It indicates that teachers' intervention also contributes to reducing the negative effect of globalization, directly determining the students' nationalistic attitude.
\end{abstract}

\section{Introduction}

Nationalism is the feeling of proud of being a part of motherland and nation ending up in the wish to make something that can make motherland and nation reputable. For that reason, education is needed to create good attitude and personality (Taufiq \& Rokhman, 2020). Love for motherland can be defined as how to think, to take stance, and to take action indicating loyalty, care, and high appreciation to nation's language, physical, social, cultural, economic, and political environments. The love-for-motherland spirit can also be called patriotism, while the feeling of love for nation can be called nationalism. Time and technology development, in addition to be beneficial, is also adverse, in which people tend to be individualistic and socializing inadequately with surrounding citizens. Technology sophistication also makes Indonesians socializing rarely with others (Hadi, 2018). Developing the feeling of love-formotherland and nation belongs to the items contained in the third principle of Pancasila, the Unity of Indonesia. Thus, Indonesians should develop their feeling of love for motherland and nation as the implementation of Pancasila. Recently, the feeling of love for motherland is getting fader, particularly in the young generation as the next generation of nation (Sugiman, 2017). It should be dealt with 
immediately to prevent it from impairing the stability of state and to equip the people in order to be good citizens.

The people's improved consciousness of nation's high cultural values is a means of generating the spirit of nationalism that can be accomplished through keeping cultivating the sense of nation and state's unity and integrity in living within society. Cultural value internalization is very important to prevent the students from feeling learning boredom (Muchsini \& Siswandari, 2020). The nation's wish to be united in Republic of Indonesia unitary state is the basic requirement to bring nationalism into reality. Thus, it is unreasonable to question ethnic, religion, race, cultural, and class diversity. The wish to be united as a nation will result in the readiness to sacrifice self-interest for the sake of upholding unity and integrity values. Love for motherland should be applied to our family, school, campus, or residence environment daily, because character degradation in young generation will have impact on degraded nationalism or love for motherland. Therefore, character and culture should be included into education development in Indonesia (Qodriani \& Kardiansyah, 2018). The degraded character of young generation today indicates the fading nationalism. Love for motherland is an obligation of individual citizens living in a sovereign country, because loving their motherland amounts to maintaining the state's sovereignty.

The implementation of love for motherland can be done in many ways, because Indonesia is a nation rich of natural wealth and local culture including local song, batik, and local tradition reasonable to preserve. Therefore, nationalism is required to support the organization and the safeguard of a state (Avci et al., 2017). Globalization current in cultural, technological, political, and economic sectors should be beneficial to improve Indonesians' self-confidence in its natural richness and local culture advantages. Habituation in education can grow character well in the students (Zaenuri et al., 2017). Habituation can be done since primary school age by inviting them to love their own culture and to use local products, expectedly inculcating the love for motherland earlier. Thus, education should be the focus of policy makers' attention to implant nationalistic values as a national development attempt (Faisal et al., 2020).

The role of teacher becomes very important in creating nationalism character among students. Interaction is very important in creating students' attitude and moral (Zhang et al., 2020). Nationalism is something every individual, particularly students, should have, because it becomes an important capital in the development process in living within nation and state. A teacher serves not only to deliver material but also to inculcate attitude and value to students (Selman \& Jaedun, 2020). In teaching-learning process, a teacher not only delivers material, but should also attempt to make the learning material delivered joyfully and to grow character values inside students. Teachers integrate values into students through their creativity in developing learning model (Parwati, 2015). The higher the teachers' ability of implementing teaching-learning process, the higher is the teachers' success in inculcating character values to students. The learning, in addition to deliver material, can also insert good character into students (Raharjo et al., 2017). The importance of inculcating nationalism into education is affected significantly by teachers' ability of applying civic education to school environment.

One of problems encountered in Indonesia today is the fading spirit of nationalism in young generations, as indicated with the present generations preferring foreign culture to their original culture (Rahman, 2019). This problem should be solved immediately because the citizens with weak nationalism will harm the state. Moreover, they can threaten the state's resilience, whether socially, culturally, economically, or politically. Considering a news coverage in Kompas daily (Setyowati, 2019) on January 15,2019 , one of problems encountered by Indonesians is weak nationalism because Indonesians prefer foreign culture to their own culture and it is difficult for them to maintain unity and integrity. If it is neglected, it will seriously threaten the sustainability of Indonesians because nationalism is an essential element the citizens should have. Due to globalization, moral problems in adolescents needs attention urgently (Rifai, 2021). The moral intended includes respecting others' rights inadequately, free sex, and degraded ethic. If this negative effect is leaved, it will threaten the state development due to the bad next generation (Agus \& Zulfahmi, 2021). The next generation should be equipped with strong character as the foundation to take action. The strong character foundation should be given to the next generation as early as possible to deal with globalization effect (A et al., 2020). It is intended to reinforce the foundation for citizens to deal with the globalization challenge in the future. The implantation of character value can be accomplished through using learning material at school for the sake of improving the students' character (Citra et al., 2021). Character implantation in dealing with globalization can be accomplished through learning material content such as civic education with teachers playing supporting role. Young generations should get attention priority because they are the ones continuing the leadership chain in the future (Farizal \& Ismaniar, 2020). Considering the argument aforementioned, it can be seen that attention should be paid to the development of young generation in order to have good character to be prepared for being leaders. Globalization leads the young generations to prefer having consumptive and individualistic 
behavior (Nanggala \& Malihah, 2020). It should be overcome as immediately as possible to prevent them from having negative attitude and even degraded moral.

The development of new modern culture or habit owing to technology advance $\mathrm{c}$ is the result of globalization enabling the people to know other states' cultures. The difference of cultural conditions between one area and another results in distinctive peculiarity (Oktarini, 2019). The effect of foreign culture incompatible to Indonesian culture should be anticipated by government in order to maintain and event to improve its citizens' nationalism. On the other hand, Indonesian government still needs much effort to integrate Indonesian culture into education curriculum material to make the material more transformative or integrated (Rochmat, 2018). Therefore, educational activists should conduct an indepth nationality study since primary education level. Because primary education provides basic knowledge on nationality, students will begin to know their state and nation's history. School should be able to organize an education oriented to science, conduct, and character comprehensively (Mustakim et al., 2019).

Education is required to inculcate nationalistic values into students earlier. The role of teachers is desirable in the implementation of civic education through various school activities to inculcate nationalistic value to primary school students (Firmansyah \& Sulistiawan, 2017). A special treatment is needed to improve citizens' nationalism. If it is left, nationalism issue can be a bigger threat. For example, Indonesia will be colonized just like it was in the past, but it is colonized not only territorially but also culturally that will threaten national resilience, viewed from economic, political, and other aspects. It, of course, will make Indonesia the poor state. Moreover, Indonesians, particularly the youths, appreciate poorly their original culture (Kristianto, 2020). Nationalism issue is difficult to solve and should be taught to citizens (Wijayanto J \& Marzuki, 2018). If young generations are less interested in original culture continuously, they will not have sense of nationalism and respect. Therefore, the role of education, in this case the role of teacher, is desirable to build the sense of nationalism. Many studies have been conducted on the improvement of civic education, but they focused on the improvement of learning with innovative learning model only (Ana, 2018; Lukiyah, 2017; Mariana, 2019; Rahmi, 2019; Rizki, 2018; Tono, 2018). Meanwhile, in globalization era not only academic achievement should be improved but also nationalism attitude is urgent to make the students' character in line with the improvement of their learning achievement in school. Therefore, this research focuses on the role of teacher in implementing civic education. Students will imitate their teachers' behavior in the class or students will make teachers their role model, because the best education is to give example or good habituation. To influence the students, habituation should be done not only in but also out of the class (Agung, 2017). Considering the habituation made daily by teachers and students, it can be seen that education builds on habituation rather than on the treatment using innovative learning for 1 (one) or 2 (two) months, because habituation will have longterm effect on students (Sulistiyarini et al., 2021). This research aims to give a real description on what the role of teacher is in the implementation of civic education. In addition, this research also attempts to reduce negative effect of globalization. Therefore, the result of research is expected to give input to educational activists, particularly primary school teachers, to improve their role in implementing civic education in many activities in their schools.

\section{Method}

This study was a descriptive qualitative research, with 255 th graders of Elementary School in the school year of 2019/2020 in SDN Badran Surakarta Indonesia being the participants. A descriptive qualitative research is a research method attempting to describe and to interpret object in the way it is (Sugiyono, 2011). Data source used was the result of interview, observation, survey, and library study. Techniques of collecting data used were observation, interview, and library study. Data validation was conducted using technique and source triangulations by analyzing students' attitude to: (1) problem solving through discussion; (2) race, ethnic, and religion diversity; and (3) Indonesian original local culture and product. Then, the result of research is connected to the result of interview, observation, and document using Miles \& Huberman's interactive analysis. Interactive analysis consists of four stages: data collection, data reduction, data display, and conclusion drawing or verification (Milles \& Huberman, 1992).

\section{Result and Discussion}

Internalization of nationalism in this research focuses on the role of teacher in implementing civic education in school by inculcating nationalistic values through some activities, either directly or indirectly, making the students love their own state. The activities organized by teachers also make the students 
have good attitude, through moral and behavior inculcation. This research analyzes character education activity in the fifth grade of primary school. There are four aspects of activities implemented by teachers both in and out of the class in school. The role of teachers related to the internalization of nationalistic values into elementary school is to create the students' attitude to:

\section{Problem solving through discussion}

One attempt taken to implant nationalistic values in students is to solve the problem through discussion, because this activity is in accordance with the values of Pancasila as Indonesia's National Principle (ideology). Pancasila values have been approved to be kindness values that should be implanted to each of Indonesian souls (Handitya, 2019). This activity is important to implant nationalism to students to enable them to learn how to solve problem corresponding to Pancasila values through discussion to get consensus rather than through hostility (Asmaroini, 2017). Through the activity, nationalistic values will be implanted automatically to students in the form of ideological value implementation. Pancasila is Indonesia's national foundation and way of life. Therefore, studies on the implementation of Pancasila through civic education learning is essential (Sumardjoko \& Musyiam, 2018). Discussion here includes the courage to express opinion, to appreciate others' opinion, and to establish close relationship between fellow citizens. Teachers play a very important role in creating the school citizens' habit (Ling et al., 2020). Therefore, teachers can create a discussion habit in solving problem in the class and to train the students to implement the principles contained in Pancasila as the part of nationalism internalization. The result of survey on students using questionnaire after the teacher habituated discussion in the class is presented in Table 1.

Table 1. Students' enthusiasm level in attending discussion

\begin{tabular}{llcc}
\hline No. & Enthusiasm level & Number of Students & Percentage \\
\hline 1 & High & 18 & 72 \\
2 & Medium & 5 & 20 \\
3 & Low & 2 & 8 \\
\hline & Total & $\mathbf{2 5}$ & $\mathbf{1 0 0}$ \\
\hline
\end{tabular}

The table shows that $72 \%$ students participate actively in class discussion. Then, $8 \%$ students are those talking with friends, making noise, and not attending the discussion, belonging to low category. So, students are trained to attend discussion actively to learn how to be good citizens. The integration of Pancasila moral value into civic education is very effectively, one of which is through discussion (Ling et al., 2020). Discussion is conducted routinely every Monday to discuss the problem in the class to train the students to solve problem corresponding to Pancasila values. Indonesians should be built based on Pancasila values as high personality through applying discussion to solve problems in daily life (Adha \& Susanto, 2020). The implementation of discussion corresponding to Pancasila values is very important to be implanted to students to make them love their state better. In an interview, a student said: "I like this discussion because I can express my opinion to solve some problem in the class like the head of class election, to make decision on some problems, to avoid hostility, and to get consensus". (Informant, October 12, 2020)

Considering the elaboration above, students can implement directly and imitate the students inculcated in the discussion as exemplified by the teachers. This discussion activity should pay attention to culture and its implementation to Indonesians (Fahriana, 2018). This discussion is closely related to the characteristics of a good Indonesian in solving a problem. Pancasila adheres to the principle of discussion for consensus, thereby creating freedom to express opinion for the citizens (Febriansyah, 2017). It can grow love for motherland as it can establish affection for friends and mutual appreciation. In addition, it can remind the students to prioritize problem solving through discussion for consensus rather than voting.

\section{Race, ethnic, and religion diversity}

Indonesians consist of diverse races and customs. There are 656 races and 300 local languages (Basyriah, 2019). Poor reading culture (literacy) in Indonesians, of course, makes many cultures still unknown (Muslimin, 2018). The diversity is Indonesia's richness that should be maintained and preserved, and thereby can give the people tranquillity and peace and prevent any problems from occurring and leading to national disintegration. Indonesian diversity should always be maintained as it contains the nation's high value (Kariadi \& Suprapto, 2017). Education to respect fellow citizens with different races, ethnics, and religions is very important to implement in the attempt of internalizing 
nationalistic values. Teachers play a role in implementing civic education, i.e. to teach students to respect other students with different cultural backgrounds and religions. Teachers also play important role in implanting attitude and value in meaningful learning to the students (Asrial et al., 2020). "I have a friend coming from Kalimantan using language different from mind, but I love to make friend with him because the difference is instead pleasing, and I can know some cultures coming from Kalimantan from my friend, and he also often asks for some information about my Javanese culture. It is so great. Moreover, my teacher also teaches me to make friends with anyone regardless their races or culture, because we are one, Indonesia". (Informant, 19 October 2020)

Considering the result of interview above, it can be seen that the fifth graders can apply nationalistic values in relation to the attitude appreciating fellow Indonesians, regardless ethnic and religion difference. Religion is not an enemy to Pancasila but instead a part of Pancasila (Fathani \& Qodir, 2020). The role of teacher in implementing civic education can be seen from students' response in an interview, stating that their teachers always teach the attitude of appreciating fellow human beings. Considering this, it can be seen the important role of teachers in implanting the value of tolerance to different races and religions. Teachers' competency is very important in giving experience and habituation with good values to students (Feriyenci et al., 2020). This implantation can be the foundation of nationalism internalization that should be done earlier in the primary school age-children. Nationalistic values related to tolerance or respect to others that should be maintained today is religious tolerance. Respect and appreciation to different religions are important to maintain and preserved (Hartanti, 2019). Tolerance can be manifested, among others, into respecting each individual's right to choose his/her own religion, giving space for worship, and so on. Mutual respect is the form of successful internalization of Pancasila values (Wardani, 2019). In an interview concerning the attitude to friends with different religion, a student said: "I respect my friends undertaking their worship, because my teacher said that we should respect others with different culture, for example: on fasting month my Christian friends did not eat and drink before me, but they did it while hiding to prevent me from seeing them. Therefore, I should also respect my friends when they do worship (Informant, October 19, 2020)

Considering the citation above, it can be seen that students can apply tolerance because they do not discriminate their friends with different religion. It is due to habituation made by teachers during teaching either in or out of the class. It is an important factor in implanting nationalistic value as tolerance to fellow religious humans. Tolerance as a part of Indonesian culture contributes considerably to unite different races/ethnics (Huda \& Khasanah, 2019). Thus, it can be seen that tolerance is the key to peace that should be preserved. Culture of a region is different from that of another. Different creeds, races, and skin colors, are typical characteristics to be proud of in the world (Ukiyatiningsih, 2019). Tolerance will prevent discrimination and is a social relation that will maintain the wholeness of fraternity regardless diversity.

\section{Indonesian original local culture and product}

Another role the teachers can play in implementing civic education is to give the students the reason why they should love Indonesian original cultural and product. Culture is an important element that should be preserved in a state (Gede Parma et al., 2020). Nationalism relates to Indonesia's characteristic and national identity that can be indicated through using Indonesian original product, like wearing batik or traditional clothes when attending an event. Wearing batik indicates the feeling of being proud of Indonesian original product (Alamsyah, 2018). Each region has different batik motif and distinctive uniqueness so that it is unsurprising that many tourists buy and even collect batik when visiting a region. "I like wearing batik because its motif is good and it comes from my region, and it is the manifestation of my love for my state and my interpretation on our state culture". (Informant, October 26, 2020)

Considering the statement above, it can be seen that the fifth grader is proud of his state cultural heritage as the manifestation of nationalism and love for their motherland. The development of education paradigm should consider the implantation of nation's high values (M. Ridwan, 2020). It can be seen that teachers play an important role in implementing civic education related to nationalism values to students. Good character can be implanted through school education with appropriate method (Nizarani et al., 2020). It is essential because the inculcation of nationalistic values is effective the primary school age, because in that age, the students can be taught and absorb nationalistic value easily. Some students rarely/never use their own culture because they do not know it and feel that the culture is outdated, so that they prefer foreign culture.

Indonesia is a very broad archipelago state, with many islands and diverse races. This race diversity leads to diverse customs and cultures (Gunawan et al., 2020). Nevertheless, Indonesians can make the diversities their power. To preserve the state's culture, Indonesians should not be influenced by 
other states' culture and should sort which culture is and is not appropriate to their culture. A strategic developing measure is required to maintain Indonesian cultures in globalization era (Hidayat \& Komariah, 2017). Foreign cultures penetrate easily into Indonesians in globalization era. In the presence of many foreign cultures, Indonesians should make their culture their self identity and an opportunity of introducing Indonesian culture. Culture is accommodated in Pancasila through intercultural principle that is open and active in nature (Pattipeilohy, 2018). Although foreign cultures are considered as more modern and associative, Indonesian cultures are equally good. There is only a few of foreign culture, but there are so many Indonesian cultures. They, of course, should be preserved by Indonesians themselves. In an interview concerning the opinion on local dance, a fifth grader said: "I like these local dance movements, because they are beautiful and, meaningful, and Indonesian cultural heritages that should be preserved" (Informant, October 26, 2020)

Considering the result of interview, it can be seen that the fifth grader like local dance as the culture to be preserved. Indonesian cultures are ancestral heritage important to be preserved as nation's self identity (Adiansyah, 2017). In addition, most of the fifth graders (72\%) also like local dance movement. So, they also like each of movements contained in local dance and it is very appropriate to implant nationalistic values related to loving the state's culture. Good preserving method makes sociocultural diversity the peculiarity and typical characteristic of Indonesians (Hamzah, 2017), so that local culture will never be extinct and be everlasting.

\section{Discussion \\ Problem solving through discussion}

Discussion about nationalism is important because conflict often occurs due to the problems unsolved in peace. Discussion can be used as a means of overcoming dissension due to globalization (Pudjiastuti et al., 2020). Actually, the conflict will not occur when it is solved through discussion rather than violence. Dissenting opinion managed incorrectly will result in dissension (Rakhmawati, 2019). If leaved, violence will likely result in break among Indonesians. It cannot be leaved, and solution should be looked for to the problem. The problem of dissenting opinion cannot be leaved to occur continuously, so that discussion is required to get consensus (Muzakkar et al., 2020). A solution to the problem is to hold discussion, the result of which is mutual consensus acceptable to both parties. Dissenting opinion should be solved in peace and taught as early as possible to young generation (Purba, 2020). The discussion cannot be implemented directly, but it should be habituated as early as possible. It is here that the education, particularly teacher of civic education, functions to implant the habit. Discussion can be done in the class in both large and small scopes to train the students to solve the problem (Supriyati, 2020), because Civic Education teachers face directly the students in implanting good character.

Thus, the result of research showing that $72 \%$ of students can participate actively in discussion indicates that they enjoy the activity held by their teachers. In addition to triggering students to participate actively, discussion also effectively trains the students to solve problems jointly (Dewi, 2020). It indicates that the teachers of elementary school, particularly in civic education field, evidently implant problem solving skill effectively through discussion, thereby not resulting in conflict or dissension. Teacher's basic duty is not only to teach material to students but also to train the students to learn actively (Syeriduni, 2020). This will equip the students later to have integrity because they are trained to avoid dissension constituting the part of nationalism they should have.

\section{Race, ethnic, and religion diversity}

Indonesia is an archipelago state; therefore, its people living in different islands have different ethnics and religions. Diversity is one of pillars that should be maintained for the sake of the state's unity (Wijenar, 2020). The diversity is God's blessing as it makes Indonesia having many ethnics and religions. However, ethnic diversity can result in conflict in human beings living together in a group (Tabi'in, 2020). Also, it can be threat, because conflict occurring due to ethnic diversity can break the state. The diversity even can result in resentment between one ethnic and another (Ganari \& Ismunarno, 2019). This is of course unexpected; therefore, the attitude respecting difference should be improved in the citizens. Peaceful and harmonious life needs the attitude respecting different religions and ethnics (Lestari et al., 2020). Respect is very important attitude because it can make a citizen can accept another's difference. The cultural asset should be maintained to prevent communal, sectarian, and political escalation conflicts from occurring (Prasojo \& Pabbajah, 2020). Respect should be implanted to the next generations as early as possible, because earlier is better. The next generation will grow with such respect, thereby solving the dissension occurring due to different ethnic and religion.

The result of research shows $82 \%$ of students can respect ethnic, race, and religion difference. It indicates that the more visible role of teacher in implanting the values in daily activity at school. Education 
should also equip the students the attitude respecting fellows and other good characters (Harahap, 2020). That is important because students can imitate directly the attitude or character of the teacher becoming their role model. Teacher's role not only change students' mindset but also gives them good model for example (Siahaan, 2019). Then, students can also seem to be able to respect their friends' difference; it can be seen from their attitude respecting their friends' worship, different ethnic, and etc, and it is inseparable from the role of primary school teachers in Civic Education subject.

\section{Indonesian original local culture and product}

Broad territory makes Indonesia having many unique and diverse cultures. Original culture can be competitiveness and appeal to attract tourists (Destriyani et al., 2020). In addition, Indonesian original products, including food, electronic, clothing, and other products, also have good quality equal to other states. The introduction of original cultural product is one of nation's assets to promote its state (Wibowo \& Kurniawati, 2020), because this can be advantage to be exported abroad or to attract foreign tourists to come to Indonesia. National cultural expression very potentially becomes a national economic source (Santyaningtyas et al., 2020). On the other hand, in fact many Indonesians instead prefer foreign product to domestic product because they consider that it is more prestigious. Batik is a cultural heritage recognized by the world because of its high quality and historical value (Triana \& Retnosary, 2020). Meanwhile, viewed from quality, although Indonesia's original product is equally good, poor love for original product makes Indonesia's product is appreciated poorly. The culture can be developed to improve its quality (A. M. Ridwan, 2018). Love for local culture and product should be implanted earlier through education, as it effectively inculcates nationalistic values. Positive effect can be implanted through character education such as nationalism in school environment, to enable students to love their own culture better (Supriyanto, 2020). Therefore, the author sees the urgency to study more in-depth the role of education in improving nationalism value.

The result of research shows that $80 \%$ of students love and want to know Indonesian culture. It indicates that school should be able to develop its local potency to be taught to students and to develop it better (Kusumaningrum et al., 2020). It is inseparable from the role of Civic Education teachers who always explain the diversity of Indonesian original cultures and products during the learning process. Teachers should be able to develop students' potency and to stimulate them to know anything (Billy \& Taat, 2020). Some activities out of school hour can make students knowing better Indonesian original cultures and products as well.

\section{Conclusion}

Considering the result of research and discussion, teachers play some roles in implementing civic education: firstly, to teach discussion in solving problem in the class with enthusiasm level o $72 \%$. It is included into the implantation of nationalistic values, as it is in accordance with the fourth principle of Pancasila. Secondly, teachers train students not to discriminate friends by races or ethnics and religions, and not to condemn their friends with different races/ethnics and religions, with score of $82 \%$, meaning that students have good tolerance as citizens. Lastly, teachers teach students to love Indonesian original culture and product, with score of $80 \%$ indicating that students love local cultures and product. Thus, attitude shown by most of students results from teachers' action or treatment either in and out of the class. The result of research can represent how teachers, as the instructors, implement civic education, particularly in internalizing nationalism into school. In addition, this result can be input to educational activists to give more in-depth intervention concerning how they teach by including character education.

\section{References}

Adha, M. M., \& Susanto, E. (2020). Kekuatan Nilai-nilai Pancasila dalam Membangun Kepribadian Masyarakat Indonesia. Al-Adabiya: Jurnal Kebudayaan Dan Keagamaan, 15(1), 121-138. https://doi.org/10.37680/adabiya.v15i01.319.

Adiansyah, R. (2017). Persimpangan Antara Agama dan Budaya (Proses Akulturasi Islam dengan Slametan dalam Budaya Jawa). Jurnal Intelektualita: Keislaman, Sosial Dan Sains, 6(2), 295-310.

Agung, I. (2017). Peran Fasilitator Guru dalam Penguatan Pendidikan Karakter (PPK). Perspektif Ilmu Pendidikan, 31(2), 106-119. https://doi.org/10.21009/pip.312.6.

Agus, E., \& Zulfahmi. (2021). Pengaruh Globalisasi Terhadap Nilai Nasionalisme Pancasila. Iuris Studia Jurnal Kajian Hukum, 2(1), 26-38.

Alamsyah. (2018). Kerajinan Batik dan Pewarnaan Alami. Endogami: Jurnal Ilmiah Kajian Antropologi, 1(2), 136-148. https://doi.org/10.14710/endogami.1.2.136-148. 
Ana, N. Y. (2018). Penggunaan Model Pembelajaran Discovery Learning dalam Peningkatan Hasil Belajaran Siswa di Sekolah Dasar. Jurnal Ilmiah Pendidikan Dan Pembelajaran, 2(1), 21-28. https://doi.org/10.24036/fip.100.v18i2.318.000-000.

Asmaroini, A. P. (2017). Menjaga Eksistensi Pancasila dan Penerapannya bagi Masyarakat di Era Globalisasi. JPK: Jurnal Pancasila Dan Kewarganegaraan, 2(1), 50-64.

Asrial, Syahrial, Maison, Kurniawan, D. A., \& Piyana, S. O. (2020). Ethnoconstructivism E-Module to Improve Perception, Interest, and Motivation of Students in Class V Elementary School. JPI (Jurnal Pendidikan Indonesia), 9(1), 30-41. https://doi.org/10.23887/jpi-undiksha.v9i1.19222.

Avci, A. A., IBRET, B. Ü., \& AVCI, E. K. (2017). Social Studies Teachers' Views Related With The Value of The Patriotism is Given at Social Sciences. Elementary Education Online, 16(4), 1558-1574. https://doi.org/10.17051/ilkonline.2017.342974.

Basyriah, A. (2019). Meningkatkan Kemampuan Siswa dalam Memahami Berbagai Keragaman Suku di Indonesia melalui Penerapan Metode Pembelajaran Mind Mapping. JPG: Jurnal Penelitian Guru FKIP Universitas Subang, 2(2), 493-501.

Billy, L. J., \& Taat, M. S. (2020). Budaya Sekolah: Hubungannya dengan Komitmen Guru. Malaysian Journal of Social Sciences and Humanities (MJSSH), 5(10), 207-216. https://doi.org/10.47405/mjssh.v5i10.511.

Citra, T. F., Listyarini, I., \& Damayani, A. T. (2021). Analisis Penanaman Nilai Karakter Siswa Kelas I menggunakan Media Boneka Tangan dengan Metode Bercerita di SD Negeri Karangsymber 02 Kecamatan Winong Kabupaten Pati. Paniti, 1(1), 24-29.

Destriyani, S. W., Andriyani, L., \& Usni. (2020). Strategi Diplomasi Budaya untuk Meningkatkan Ekspor Batik Indonesia ke Jepang. Independen: Jurnal Politik Indonesia Dan Global, 1(2), 107-120. https://doi.org/10.24853/independen.1.2.107-120.

Dewi, D. M. R. (2020). Mengefektifkan Model Small Group Discussion (Diskusi kelompok kecil) Upaya Meningkatkan Motivasi dan Hasil Belajar Agama Hindu Peserta Didik Kelas IV Semester Dua Tahun Pelajaran 2018/2019 di SD Negeri 7 Mataram. JISIP (Jurnal Ilmu Sosial Dan Pendidikan), 4(2), 30-39. https://doi.org/10.36312/jisip.v4i2.1065.

Fahriana, A. S. (2018). Pengambilan Keputusan Secara Musyawarah dalam Manajemen Pendidikan Islam: (Kajian Tematik Al-Qur'an dan Hadist). Al-Hayat: Journal of Islamic Education, 2(1), 17-46.

Faisal, Gi, G. M., \& Martin, S. N. (2020). Analysis of Government-Funded Research in Indonesia from 20142018: Implications for Research Trends in Science Education. Jurnal Pendidikan IPA Indonesia, 9(2), 146-158. https://doi.org/10.15294/jpii.v9i2.23174.

Farizal, A., \& Ismaniar. (2020). Pendekatan Andragogi dalam Pemberdayaan Generasi Muda melalui Pendidikan Luar Sekolah. Jurnal Pendidikan Tambusai, 4(3), 3289-3293.

Fathani, A. T., \& Qodir, Z. (2020). Agama Musuh Pancasila? Studi Sejarah dan Peran Agama dalam Lahirnya Pancasila. Al-Qalam, 26(1), 117-128.

Febriansyah, F. I. (2017). Keadilan berdasarkan Pancasila sebagai Dasar Filosofis dan Ideologis Bangsa. DiH: Jurnal Ilmu Hukum, 13(25), 1-27.

Feriyenci, A., Suryana, E., \& Zainuri, A. (2020). Manajemen Pengembangan Sumber Daya Manusia dalam Mewujudkan Sekolah Model di SD Nurul Ilmi Kabupaten Banyuasin. Jurnal Intelektualita: Keislaman, Sosial Dan Sains, 9(2).

Firmansyah, S., \& Sulistiawan, H. (2017). Peran Guru Pendidikan Kewarganegaraan dalam Mengembangkan Nilai Moral Yang Terkandung dalam Materi Demokrasi di Kelas VIII SMP Negeri 1 Sungai Raya Kepulauan Kabupaten Bengkayang. Jurnal Pendidikan Kewarganegaraan, 1(1), 5865.

Ganari, M. A., \& Ismunarno. (2019). Pertanggungjawaban Pidana terhadap Penyebaran Informasi Suku Agama Ras dan Antargolongan yang Menimbulkan Permusuhan dan Kebencian. Jurnal Recidivice, 8(2), 187-194.

Gede Parma, P., Pratiwi, D. K. I., \& Bayu, G. W. (2020). Bali Culture Exploration in Development of Friendly Science Teaching Materials for Hearing and Speaking Impairment Students at Inclusion School. Jurnal Pendidikan Indonesia, 9(1), 142-152. https://doi.org/10.23887/jpi-undiksha.v9i1.24354.

Gunawan, H., Septiana, Y., \& Gunadhi, E. (2020). Rancang Bangun Media Pembelajaran Pengenalan Ragam Budaya Indonesia Berbasis Android. Jurnal Algoritma, 17(1), 82-90.

Hadi, A. (2018). Bridging Indonesia's Digital Divide: Rural-Urban Linkages? Jurnal Ilmu Sosial Dan Ilmu Politik, 22(1), 17-33. https://doi.org/10.22146/jsp.31835.

Hamzah, M. M. (2017). Peran dan Pengaruh Fatwa MUI dalam Arus Transformasi Sosial Budaya di Indonesia. Millah: Jurnal Studi Agama, 127-154. https://doi.org/10.20885/millah.vol17.iss1.art7.

Handitya, B. (2019). Menyemai Nilai Pancasila pada Generasi Muda Cendekia. Adil Indonesia Jurnal, 2(1), 
13-23.

Harahap, D. S. (2020). Upaya Peningkatan Hasil Belajar Siswa pada Tema Bangga sebagai Bangsa Indonesia dengan Menggunakan Metode Diskusi di Kelas V SD Negeri 200307 Padangsidimpuan. Jurnal ESTUPRO, 5(2), 23-32.

Hartanti. (2019). Peningkatan Hasil Belajar Materi Analisis Prinsip Persatuan dalam Keberagaman Suku, Agama, ras, dan Antargolongan (SARA) Sosial Budaya, Ekonomi, dan Gender dalam Bingkai Bhinneka Tunggal Ika melalui Metode Jigsaw Learning. Jurnal Education and Economics, 2(1), 3043.

Hidayat, D., \& Komariah, S. H. (2017). Pengukuran Tingkat Pengenalan Pengguna Games terhadap Muatan Budaya Indonesia pada Mobile Game Berbasis Android (Studi Kasus: Dakon, Karapan Sapi dan Temple Rush Prambanan). Jurnal Rekayasa Sistem \& Industri, 4(1), 31-36.

Huda, M. T., \& Khasanah, I. (2019). Budaya sebagai Perekat Hubungan Antara Umat Beragama di Suku Tenger. SANGKéP: Jurnal Kajian Sosial Keagamaan, 2(2), 152-170.

Kariadi, D., \& Suprapto, W. (2017). Membangun Kepemimpinan berbasis Nilai-nilai Pancasila dalam Perspektif Masyarakat Multikultural. Citizenship Jurnal Pancasila Dan Kewarganegaraan, 5(2), 8696.

Kristianto, A. W. (2020). Peran Generasi Penerus Bangsa Dalam Mempertahankan Budaya Bangsa Indonesia (The Role of the Nation's Next Generation in Defending Indonesian Nation's Culture). Available at SSRN 3628399, 8(2), 2019.

Kusumaningrum, D. E., Sumarsono, R. B., \& Gunawan, I. (2020). Pengaruh Kepemimpinan Pembelajaran, Kepemimpinan Perubahan, Kepemimpinan Spiritual, Budaya Sekolah, dan Etika Profesi terhadap Kinerja Mengajar Guru. JMSP (Jurnal Manajemen Dan Supervisi Pendidikan), 4(3), 198-219.

Lestari, R. D., Rokim, \& Aslamiyah, S. S. (2020). Internalisasi Nilai Pendidikan Agama Islam dalam Membentuk Sikap Toleransi Antarumat Beragama. SAWABIQ: Jurnal Keislaman, 1(1), 1-8.

Ling, Z., Na, J., Yan-Li, S., \& Sriyanto, J. (2020). School Culture and Professional Development of School Teachers from Urban and Rural Areas in China. Cakrawala Pendidikan, 39(3), 609-619. https://doi.org/10.21831/cp.v39i3.31580.

Lukiyah, L. (2017). Efektivitas Model Pembelajaran Numbered Head Together (NHT) terhadap Peningkatan Hasil Belajar Siswa dalam Pembelajaran PKn ( Penelitian Tindakan Kelas) pada Siswa Kelas VI SDN Randuagung 05. Jurnal PTK Dan Pendidikan, 3(1). https://doi.org/https://doi.org/10.18592/ptk.v3i1.1058.

Mariana. (2019). Peningkatan Pembelajaran PPKN Materi Persiapan Kemerdekaan Indonesia Melalui Pendekatan Contextual Teaching And Learning (CTL) Pada Siswa Kelas VI SD Negeri Muka Blang. Jurnal Sains Riset, 9(1), 29-42.

Milles, M. B., \& Huberman, A. M. (1992). Analisis Data Kualitatif (T. R. Rohidi \& Mulyarto (eds.)). Universitas Indonesia Press.

Muchsini, B., \& Siswandari. (2020). Class Culture and The Academic Stress of Digital Natives Generations. Cakrawala Pendidikan, 39(1), 102-110. https://doi.org/10.21831/cp.v39i1.26910.

Muslimin. (2018). Penumbuhan Budaya Literasi melalui Peningkatan Minat Baca Masyarakat Desa. Cakrawala Pendidikan, 37(1), 107-118.

Mustakim, Z., Chamdani, M., \& Mahmudah, U. (2019). Comparison of Efficiency School Performance between Natural and Social Sciences: A Bootstrapping Data Envelopment Analysis. Cakrawala Pendidikan, 38(2), 282-292. https://doi.org/10.21831/cp.v38i2.22837.

Muzakkar, Sultan, \& AJ, A. A. (2020). Analisis Tuturan Penolakan dalam Diskusi Kelas. Jurnal Pembelajaran Bahasa Dan Sastra Indonesia, 1(1), 18-24.

Nanggala, A., \& Malihah, E. (2020). Peran Tradisi Irung-Irung dalam Memperkuat Civic Engagement Generasi Muda di Kabupaten Bandung Barat. Jurnal Ilmiah Pendidikan Pancasila Dan Kewarganegaraan, 5(1), 1-16. https://doi.org/10.17977/um019v5i1p1-16.

Nizarani, Kristiawan, M., \& Sari, A. P. (2020). Manajemen Pendidikan Karakter Berbasis Pondok Pesantren. Jurnal Intelektualita: Keislaman, Sosial, Dan Sains, 9(1), 37-44.

Oktarini, M. F. (2019). The Spreading of Vernacular Architechture at the Riverways of South SUmatra, Indonesia. Indonesian Journal of Geography, 51(2), 199-206. https://doi.org/10.22146/ijg.44914.

Parwati, N. N. (2015). Pengembangan Model Pembelajaran Pemecahan Masalah Berorientasi Kearifan Lokal pada Siswa SMP di Kota Singaraja. Jurnal Pendidikan Indonesia, 4(2), 612-622. https://doi.org/10.23887/jpi-undiksha.v4i2.6058.

Pattipeilohy, S. Y. E. (2018). Ketuhanan yang Berkebudayaan: Memahami Pancasila sebagai Model Interkulturalitas. Gema Teologika, 3(2), 121-146. https://doi.org/10.21460/gema.2018.32.363.

Prasojo, Z. H., \& Pabbajah, M. (2020). Akomodasi Kultural dalam Resolusi Konflik Bernuansa Agama. JURNAL AQLAM - Journal of Islam and Plurality, 5(1), 1-28. 
Pudjiastuti, S. R., Ilis, N., \& Ati, H. M. (2020). Penerapan Metode Diskusi dalam Meningkatkan Pemahaman Globalisasi. Jurnal Pendidikan Dan Pengajaran Guru Sekolah Dasar (JPPGuseda), 3(2), 133-138.

Purba, F. J. (2020). Penggunaan Metode Diskusi dalam Meningkatkan Hasil Belajar. Jurnal Inovasi Pembelajaran Fisika (INPAFI), 8(1), 24-28.

Qodriani, L. U., \& Kardiansyah, M. Y. (2018). Exploring Culture in Indonesia English Textbook for Secondary Education. Jurnal Pendidikan Indonesia, 7(1), 51-58. https://doi.org/10.23887/jpiundiksha.v7i1.13692.

Raharjo, Y. M., Waluyo, H. J., \& Saddhono, K. (2017). Kajian Sosiologi Sastra dan Pendidikan Karakter dalam Novel Nun pada Sebuah Cermin Karya Afifah Afra serta Relevansinya dengan Materi Ajar di SMA. Jurnal Pendidikan Indonesia, 6(1), 16-26. https://doi.org/10.23887/jpi-undiksha.v6i1.8627.

Rahman, M. H. (2019). Pemahaman Nilai-nilai Nasionalisme Mahasiswa di Perguruan Tinggi Kota Malang. ENTITA: Jurnal Pendidikan Ilmu Pengetahuan Sosial Dan Ilmu-Ilmu Sosial, 1(1), 11-18.

Rahmi, A. (2019). Peningkatan Hasil Belajar Siswa dengan Model Problem Based Learning di Sekolah Dasar. Jurnal Basicedu, 3(4), 2113-2117. https://doi.org/10.31004/basicedu.v3i4.242.

Rakhmawati, E. D. (2019). Pengembangan Inovasi Pembelajaran pada Mata Kuliah Ilmu Alamiah Dasar dengan Metode Diskusi Kelompok. IJTIMAIYA: Journal of Social Science Teaching, 4(1).

Ridwan, A. M. (2018). Perlindungan Pengetahuan Tradisional Terkait dengan Keanekaraaman Hayati di Indonesia. Pemuliaan Hukum, 1(1), 97-124.

Ridwan, M. (2020). Pendidikan di Indonesia Menyongsong Era Disrupsi 4.0. Jurnal Intelektualita: Keislaman, Sosial Dan Sains, 9(2).

Rifai. (2021). Hubungan Tingkat Religiusitas terhadap Kecemasan Moral dan Alternatif Pembinaan Moral pada Kenakalan Siswa. Jurnal Teologi Gracia Deo, 3(2), 76-87. https://doi.org/10.46929/graciadeo.v3i2.63.

Rizki, A. (2018). Peningkatan Pembelajaran PKN dengan Penerapan Metode Role-Playing Siswa Kelas II SDN 003 Bangkinang Kota. Jurnal Basicedu, 2(1), 33-42.

Rochmat, S. (2018). Transformative Education as a Dialectic of Indonesian Culture and Modern Culture. Cakrawala Pendidikan, 37(3), 366-377.

Santyaningtyas, A. C., Khalid, R. M., \& Johan, N. F. (2020). Perlindungan Ekspresi Budaya Tradisional di Indonesia: Suatu Penilaian (Protection of Traditional Cultural Expression in Indonesia: A Legal Assessment). Jurnal Undang-Undang Dan Masyarakat, 24(2019), 25-32.

Selman, Y. F., \& Jaedun, A. (2020). Evaluation of The Implementation of 4C Skills in Indonesian Subject at Senior High Schools. Jurnal Pendidikan Indonesia, 9(2), 244-257. https://doi.org/10.23887/jpiundiksha.v9i2.23459.

Setyowati, A. (2019). Pentingnya Nasionalisme di Era Indonesia Modern Kompas.com. Kompas.Com.

Siahaan, M. (2019). Penerapan Metode Diskusi Kelompok untuk Meningkatkan Hasil Belajar Siswa pada Mata Pelajaran Matematika di Kelas VIII-1 SMP Negeri 1 Patumbak. JS (Jurnal Sekolah), 3(3), 348354.

Sugiman, A. M. R. (2017). Penanaman Nilai-Nilai Nasionalisme dan Patriotisme melalui Materi Sikap Semangat Kebangsaan dan Patriotisme dalam Kehidupan Bermasyarakat, Berbangsa dan Bernegara pada Pembelajaran PKn di SMAN 1 Pundong. Academy of Education Journal, 8(2), 174199. https://doi.org/10.47200/aoej.v8i2.370.

Sugiyono. (2011). Metode Penelitian Kuantitatif, Kualitatif, dan R\&D. Alfabeta.

Sulistiyarini, A., Sukarno, \& Triyanto. (2021). School Literacy Movement (SLM) as a Solution to Increase Reading Interest of Indonesian Students. Elementary Education Online, 20(1), 1324-1334. https://doi.org/10.17051/ilkonline.2021.01.127.

Sumardjoko, B., \& Musyiam, M. (2018). Model of Civic Education Learning based on The Local Wisdom for Revitalizing Values of Pancasila. Cakrawala Pendidikan, 37(2), 201-211. https://doi.org/10.21831/cp.v37i2.18037.

Supriyanto, E. E. (2020). Kontribusi Pendidikan Pesantren bagi Pendidikan Karakter di Indonesia. Jurnal Pendidikan NUsantara, 1(1), 13-26.

Supriyati, I. (2020). Penerapan Metode Diskusi dalam Pembelajaran Keterampilan Berbicara pada Siswa Kelas VIII MTsN 4 Palu. Jurnal Bahasa Dan Sastra, 5(1), 104-116.

Syeriduni, E. (2020). Upaya Meningkatkan Kemampuan Berfikir Kritis Siswa melalui Penerapan Metode Diskusi dengan Pendekatan Contekstual Teaching and Learning pada Tema Indahnya Negeriku di Kelas IV SD Negeri 200217 Padangsidimpuan. Jurnal ESTUPRO, 5(1), 12-24.

Tabi'in, A. (2020). Pengenalan Keanekaragaman Suku Agama Ras dan Antar Golongan (SARA) untuk Menumbuhkan Sikap Toleransi pada Anak Usia Dini. ThufuLA: Jurnal Inovasi Pendidikan Guru Raudhatul Athfal, 9(2), 137-151. https://doi.org/10.21043/thufula.v8i2.7246.

Taufiq, M., \& Rokhman, F. (2020). Scientific Communication Skills Profile of Prospective Science Teachers 
based on Sociocultural Aspects. Jurnal Pendidikan IPA Indonesia, 9(2), 187-193. https://doi.org/10.15294/jpii.v9i2.24366.

Tono, T. (2018). Peningkatan Aktivitas dan Hasil Belajar Siswa Kelas VI Mata Pelajaran PKN Materi Pokok Demokrasi melalui Penerapan Model Pembelajaran Scramble pada Siswa SD Negeri 1 Pakis Kecamatan Kradenan Tahun Pelajaran 2017/2018. Efektor, 5(1), 45-49. https://doi.org/10.29407/e.v5i1.11944.

Triana, N. N., \& Retnosary, R. (2020). Pengembangan Model Pemasaran Batik Karawang sebagai Produk Unggulan Daerah. Jurnal Inovasi Dan Pengelolaan Laboratorium, 2(1), 21-27.

Ukiyatiningsih. (2019). Upaya Meningkatkan Prestasi Belajar PPKN Materi Keberagaman Suku, Ras, dan Antargolongan Melalui Metode Problem Based Learning (PBL). Jurnal Education and Economics, 2(1), 57-67.

Wardani, W. (2019). Internalisasi Nilai dan Konsep Sosialisasi Budaya dalam Menjunjung Sikap Persatuan Masyarakat Desa Pancasila. NUSANTARA: Jurnal Ilmu Pengetahuan Sosial, 6(2), 164-174.

Wibowo, D. S., \& Kurniawati. (2020). Pengenalan Produk Budaya melalui Sejarah Jatidiri: Studi Kasus Kesadaran Sejarah di SMA Labschool Kebayoran. Dimensi, 17(1), 33-54.

Wijayanto J, R., \& Marzuki, M. (2018). Pendidikan Bela Negara sebagai Tonggak Peradaban Jiwa Patriotisme Generasi Muda. Jurnal Ilmiah Pendidikan Pancasila Dan Kewarganegaraan, 3(2), 186191. https://doi.org/10.17977/um019v3i2p186-191.

Wijenar, E. (2020). Penguatan Pemahaman Keberagaman Suku, Agama, Ras dan Antargolongan Siswa melalui Problem Based Learning. Gema Wiralodra, 11(1), 35-44. https://doi.org/10.31943/gemawiralodra.v11i1.111.

Zaenuri, Sudarmin, Utomo, Y., \& Juul, E. (2017). Habituation Model of Implementing Environmental Education in Elementary School. Jurnal Pendidikan IPA Indonesia, 6(2), 206-212. https://doi.org/10.15294/jpii.v6i2.10200.

Zhang, Y., Rebrina, F., Sabirova, F., \& Afanaseva, J. (2020). Blended Learning Environments in Inclusive Education at the University. International Journal of Emerging Technologies in Learning, 15(21), 145-161. 